\title{
The Productivity of Scientific Rhetoric
}

\section{David Depew}

Emeritus Professor, Project on the Rhetoric of Inquiry

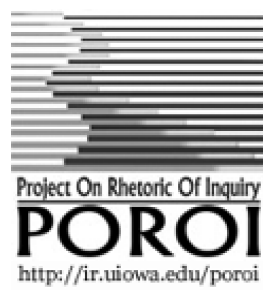

(POROI), The University of Iowa

Iowa City, IA USA

John Lyne

Department of Communication, University of Pittsburgh

Pittsburgh, PA USA

Poroi 9,1 (April 2013)

\section{Rhetoric and Contemporary Studies of Science}

The rhetoric of science is so far a small but proud scholarly field that seeks simultaneously to contribute to rhetorical studies and to secure a place for rhetoric in the conversation of-to use a broad and not exclusively owned term-science studies. We want to be mindful of both of those fronts. The approach of rhetorical studies to argumentation, including scientific argumentation, recognizes that, no matter how valid their reasoning or how strong their evidence, speakers must command authority with audiences and that audiences bring a lot of baggage with them to the context-dependent rhetorical situations in which they encounter rhetorical activity. Accordingly, rhetoricians of science take seriously the role of rhetorical choices, including the use of tropes and figures, narrative accounts, genre expectations, and terministic framing to shape conversations about science.

The field owes its gratitude to pioneers such as John Angus Campbell, Lawrence Prelli, Alan Gross, Randy Allen Harris, Jeanne Fahnestock, Carolyn Miller, and others who made this or related points at a time when the reflective study of science was still dominated by history and philosophy of science. Within the narratives of these more prestigious disciplines, the scope of rhetoric was pretty much confined to public communication of scientific results. The epistemic grounds of scientific claims were located elsewhere.

Since then, studies of science have taken so decidedly a discursive and social turn that logical-formalist philosophies and internalist histories of science are no longer taken seriously by nearly anybody (with certain exceptions that both these authors know all too well). This development raises two interlinked questions. One is whether the social-discursive turn in the study of science has taken full advantage of rhetorical theory and criticism in articulating its alternative to philosophy of science. The other is whether we rhetoricians of science have taken full advantage of the opening created by the broader discursive-social turn to articulate, deploy, and advertise our distinctive yet varied approach.

If one were to cast a net in the waters of rhetorical studies of science and technology, one would capture quite a range of projects in the last 
several decades. These include but are not limited to: (1) rhetorical analysis of major scientists; (2) the rhetoric of scientific genres; (3) rhetoric within specific scientific fields; (4) the rhetoric of science-related controversies; (5) inventional practices in science; (6) controversy-strewn episodes in the history of science; (7) public appropriations of scientific terms; (8) language and figures within science; (9) incommensurability and demarcational relationships among disciplines; (10) rhetoric and philosophical rationality; (11) the uses of scientific expertise; (12) the rhetoric of medicine, (13) rhetoric and materiality; (14) the rhetoric of risk; (15) visual rhetorics of science; and (16) the mythic rhetorics of science and religion. ${ }^{1}$ Collectively, these writings represent contributions to the theory, criticism, and history of rhetoric. And we can be proud of the many variations on a theme. But the studies do not follow a single program or share a specific agenda. Rhetoric is opportunistic and unruly, and we cast our nets where we think the fishing is good. Is this a problem? This is a fair and timely question. What would it mean to be part of a unified agenda, and what principles might provide that unity? Or, by contrast, might we embrace the concept of repertoire and still remain aspirational? Is that enough?

Perhaps it is an aspiration to find a common framework that leads us to draw upon other fields. Many among us want to make common cause with Bruno Latour, for example, and it is encouraging that this most prominent proponent of social studies of science does himself make use of the term rhetoric to describe the transactions that resulted in, for example, the pasteurization of France or the exportable, packaged bits of sellable knowledge generated by words as much as by deeds at places like the Salk Laboratories (Latour, 1988). Let us quote Latour in reference to the R-word. "Rhetoric," he observed, "is a fascinating albeit despised discipline, but it becomes still more important when debates are so exacerbated that they become scientific and technical" (Latour, 1987, p. 30). We note, too, that Latour's own rhetoric is fascinating to us. For instance, his thought experiment of ontological egalitarianism in which things as well as persons take part in the wrangling of a great parliament may have helpfully challenged the assumption that persons alone are articulate and things just get pushed around (Latour, 1993, 2007). Even as this exercise strains credulity, it leads to valuable insights. Still, Latour's inventional spark is so bold that its very success has caused him difficulties in convincing people that his case studies support local, context-dependent forms of scientific empiricism and realism. This is not the wholesale social constructionism most of his readers, especially the lazy ones, expect to hear.

We largely agree with Latour about going local and about robust contextualization. We also sympathize with his exasperated assurances that science does not either in fact or in his view reduce to textualism. Yet, here is a point at which the rhetorical perspective leads us to the

${ }^{1}$ We invite the reader's perusal of the references in Appendix A. 
contentious but attractive claim that the rhetoric of science contextualizes science better than does the sociology of science because the latter tends to reduce arguments to context rather than defining context by argument. This is for the rhetoric of science a key point. It means that context is a very flexible concept; it embraces the discursive as well as the material. In this and related matters, perhaps we rhetoricians of science can engage the social studies of science to mutual benefit, and in the process fulfill the expectations that led our founders to form this association.

Perhaps Kenneth Burke's pentadic devices for distributing agency would add something of value to Latour's argument. One of those five terms is "scene." G. Thomas Goodnight's threefold distinction between personal, technical, and public spheres of discourse, which is itself a rhetorical reconstruction of Habermas's theory of communicative action, can help frame the scene in which the kinds of transactions Latour posits take place (Goodnight, 1982). If you see it this way you will observe that only under very particular, very contingent, and very hard to sustain conditions, such as those that obtained in post-War America, can modern societies support the degree of phase separation among these three discursive spheres that grants serene autonomy to the technical sphere in ways philosophers of science tend to take for granted. Why otherwise would the intrusions of creationists and climate science deniers seem like, well, intrusions? Rhetoricians know better. The boundaries between discursive spheres are not natural. They are constructed and maintained by ongoing rhetorical activity, and even at their best, they leak at the seams.

If there is one theorem that we rhetoricians of science have sustained in ways that have suffered little back talk, it is that demarcation or boundary-work between science and society; between science, nonscience, junk science, and pseudo-science; and between various scientific fields themselves is irreducibly rhetorical. We are thinking of the work of Charles A. Taylor (1997) and of Thomas Gieryn (1999). Efforts of philosophers to try to find purely logical, Bayesian probabilistic, and other methodological ways of demarcating have been in vain. Still, the main implication of recognizing that demarcation is essentially rhetorical is both inescapable and hard to hear even for some of its supporters. Unless you define the technical sphere in a way that is both questionbegging and hopelessly unreal, it must be admitted that there is nothing in principle that prevents junk science and pseudo-science from being hatched in and passed out by reputable technical sphere venues. Nor is there anything in principle that prevents public sphere discourse from putting the burden of proof on what comes out of the mouths of scientists.

Both of these things in fact happen. It was not scientifically scrupulous progressives or scientists themselves, for example, but benighted big city Catholic politicians who did the discursive spade work that put the brakes on the eugenic laws in this country. ${ }^{2}$ The laws were

${ }^{2}$ See Kevles (1985, pp. 118-119). The Catholic hierarchy opposed eugenics not on scientific but on ethical and theological grounds. It thus put a view 
not only supported by scientists and political progressives; they had been proposed by them in the first place.

Rhetoricians are well-equipped to study cases like these because there is in them a strong sense of how contexts, events, politics, and traumas are integral and intertwined factors in the trajectories of scientific research programs. At present, many in our field are worried, with good reason, about how good science is being blocked by political opposition. We do not want to forget, however, that it has sometimes been scientists who have blocked good sense. One sometimes hears that we needn't worry about such misadventures as eugenic laws anymore because that was the result of bad science, while we, unlike the people of a century ago, practice good science and would never makes such mistakes. (Well, at least we wouldn't use eugenics as an authorizing term if we did.) Such complacency does not seem to be justified by history. Nor is the view that deviations like that can go on only for a while, since there is a built-in mechanism in scientific rationality that inevitably corrects for ideologically-inspired errors like eugenics laws or Lysenkoism in Stalin's Russia. That isn't quite how it happened in either case.

\section{Optimism About Science-and About Democratic Discourse}

Reflecting on histories like these, some science studies folks (largely constructionists) have drawn on what they call "the pessimistic induction," according to which science never gets good enough to rise above the weak forms and norms of evidence that presumably haunt public and personal spheres of discourse. If this is so, the hope of the middle class regimes that first took power in America and Europe in the 1830 s that science would serve as a corrective for the democratic institutions they were promising to erect would indeed be in vain. Irrationality would reign. Historically, in fact, we find just such bursts of

into circulation in the American public sphere that later found support from scientists. There were, of course, geneticists who dissented from eugenic programs, both positive and negative, in the 1920 s and 1930 s because they didn't think you could isolate environmental and genetical factors in human populations. Or even if you could, they doubted that you could objectively determine which traits are to be selected for and against. But these objections were pragmatic, not principled. There was a huge institutional connection between genetics and eugenics that was not fully broken even when Theodosius Dobzhansky provided compelling arguments in the 1940s that eugenics is not only impractical but biologically incoherent. Unlike the Galileo case, the Catholic Church got this one right, albeit not on scientific grounds. Other churches, especially those affected by modernist progressive movements, did not, including the Episcopalians and Methodists. This case does not mean that publics are presumptively right. They are most certainly not when it comes to creationism. But that's just the point. You never can tell until you look at the particulars in all their complexity. 
irrationality accompanied by epistemic pessimism, even nihilism, at times and places where pseudoscience thrives and democracy collapses, as it did in Germany in the 1930 s.

But what if rhetoricians of science made it their special charge to point out that this may be a false dichotomy? And conversely, what if public discourse is not always and antecedently dismissed as deficient in rationality? Even if its forms and norms of rationality are different from those of science, is it not possible, indeed likely, that public argumentation is rational enough to mix it up with science in productive, if also messy, ways? What if scientists, in order to live up to their loudly proclaimed devotion to rational inquiry, were asked reflectively to confront and reject their own prejudices, as feminist philosophers of science have, for example, been asking them to do with some success in recent years?

In that case, might one draw a different, more optimistic induction from the histories that on scientistic assumptions stimulate the pessimistic induction? Consider the case of eugenics again. If in the end things did go well, we think it was because criticism in democratically structured public venues inspired criticism in technical ones, which eventually destroyed the genetics arguments on which eugenics was predicated and prepared the ground for the reception of these arguments. It was because scientists shared the intuitions of untutored publics that they looked for and found empirical arguments that validated their intuitions. Their critique, first intimated by advocates of religion, then supported by scientists committed to liberal egalitarianism, turned into a tidal wave in the wake of revelations about Nazi science. Celeste Condit has shown that, aside from serving as a stigmatizing term, use of the term eugenics virtually ended-but, we add, it did so completely only when the story of its rise and fall was told in public venues by people like Daniel Kevles in the 1980 s.

In sum, because we rhetorical scholars are not antecedently contemptuous of public sphere and personal sphere forms of discourse, we are more upbeat about truth-finding, or at least falsehoodextinguishing, in technical sphere venues. Maybe our civic instincts make us comfortable with the idea that science is too important to be left to the scientists. While there is no magic guarantee that errors will be flushed out of science, we believe that the arc of a vigorous cross-sphere practice of rhetorical criticism of scientific claims, evidence, assumptions, and implications tends to bend toward truth, albeit situated and localized truth-just as Martin Luther King reminded us that the long arc of democracy bends toward justice. To those skeptical of appeals to truth and justice on such a large scale, let us at least offer this alternative: Good rhetoric, like good science, helps in rooting out falsity and injustice, which are far more plentiful.

\section{Discovery and Proof: An Inventional Continuum}

What justifies our optimism that rhetoric can be as good for science as it can be for justice? It is partly because, along with Fahnestock (this issue), 
Prelli (this issue), and others, we think that rhetoric (both as advocacy and as criticism) is an organon, a tool that is productive of knowledge. It extends the tentacles of conceptual grasp. It is as epistemic in its force as the rhetoric-baiting Plato and the anti-rhetorical Platonists after him took logic and mathematics alone to be.

Here we give a tip of the hat to Richard McKeon's call for rhetoric to be an architectonic productive art, even if, localists that we are, we do not share the grandeur of his ambition (Depew, 2010; Hauser \& Cushman, 1973; McKeon, 1971). During the post-War heyday of the philosophy of science, it was big news to assign to rhetoric, as he did, a role not just in marketing scientific discoveries to non-expert audiences but, more deeply, in inventing ideas that it also plays a role in subjecting to confirmation and falsification. McKeon made that case by pointing out that the logical empiricist and the Popperian distinction between the context of discovery and the context of justification is a riff on the ancient rhetorical distinction between invention and arrangement. As Jeanne Fahnestock pointed out in her excellent earlier review, Iowa's Project on the Rhetoric of Inquiry (POROI), with which both of us have been associated, was and is more or less dedicated to reviving rhetorical invention in and especially across fields of inquiry, including science (Fahnestock, 2008).

Considered rhetorically, invention in science, as in other forms of inquiry, can't be thought of in isolation from justification at all; rather, the two comprise at most dialectical poles in the dynamics of inquiry. Invention is a shared social practice, not the private, purely psychological process to which philosophers invidiously confined it in order to put the accent instead on logical justification. When one invents, it is with an eye toward how the invented argument, framing, or interpretation might hold up under the scrutiny of an audience. And sometimes that audience, including the internalized audience that any well-socialized inquiry leans upon, sends the inquirer back to the drawing board. Indeed, the critical audience (e.g., another scientist or an external critic) might not just challenge an explicit argument but also, for example, challenge the use of a dominant metaphor, which then puts it within the space of investigation and productive inquiry. While we understand that a metaphor is never precisely true or false, a metaphor that is apt for a particular phenomenon under inquiry can open whole new vistas, while a bad one can really gum up the works. So metaphors too can be, and often are, challenged and tested.

All of this makes the activity of inquiry less like a monologue than a dialogue. The scientist is, so to speak, putting down steppingstones as he or she goes, with each step testing them with one foot. Those scientific ideas that make themselves clear enough to count as testable hypotheses do so in and through debates about their merits. The process of stating a claim is inseparable from justifying it. What philosophers like to call justification, as opposed to discovery, is the perspicuous deductive display after the fact, rather like what rhetoricians once called arrangement. It may seem otherwise, as when we hear about crucial experiments like Michelson-Morley that dispose of an issue once and for all. But closer inspection shows that in such cases what has happened is that critical 
discussion has reached a point of satiation, that is, a point at which prior discourse has generated a well-formed issue that precludes the usual posing and talking past each other. The crucial experiment is both invented and tested within a field of argument, in this case whether a light-carrying medium, the ether, exists or does not. The same experiment in a different rhetorical situation would mean very little.

The rhetorical productivity that we have inadequately described comes into focus as soon as we recognize that knowledge production necessarily takes place in the space of implicit or explicit controversies (Goodnight, 1982). All controversies, whether they are scientific, political, or religious, find their natural medium in rhetorical argumentation, both on the side of advocating claims and on the side of criticizing them. This point turns out not to be trivial. It implies, for one thing, that the meaning of claims and the persuasiveness of evidence for and against them are essentially entangled with the claims they contest and the evidence for and against them. This is primarily what we mean by the localness of inquiry. Controversies are rhetorically situated.

\section{Embedded Rhetoricity}

What do we see when we look closely at such scenes of contestation? We see the productive interplay of competing accounts, models, configurations, narratives, metaphors, emphases, and authorizing terms. Let us look a bit more closely at a few of these.

Working as both of us do in the rhetoric of evolutionary biology, along with our esteemed colleagues John Angus Campbell and Leah Ceccarelli, we see the rhetoricity of ostensibly demonstrative scientific prose everywhere. Let's look at a couple of the ways this happens in a field that raises passions because it overlaps not only public and technical spheres of argumentation but also engages the personal sphere as well, where the meaning of life and the value of interpersonal relationships make themselves most felt.

\section{Selective Examples as Good Evidence}

Ever since Aristotle, let us recall, we have known that examples play a key evidential role in rhetorical argumentation as is very prominent in evolutionary biology. Evolutionary arguments rest, in fact, on persuasive examples: archaeopteryx, black and grey pepper moths, the heterozygotic superiority of blood cells that confer some immunity to malaria, and others. We are aware that these examples, which appear over and over again in textbooks, stand in for, and offer promissory notes on behalf of, many other similar cases that, authors assure us, will eventually turn up to confer general significance on the examples. We are aware, too, that, while similar cases often do show up, they are seldom enough to turn a case study into a general model or even less often to turn a good model into a law-governed theory. Neo-positivist philosophers of science like Alexander Rosenberg (1994) worry about this enough to conclude that evolutionary biology, let alone the social sciences, is not and never can be law-like enough to be a real science. 
As rhetoricians of science, however, we have a more equable attitude. We are not in the least scandalized by the fact that examples are perspicuous and paradigmatic because they are described in terms of images, analogies, metaphors, and other tropes. Why, in a specific context of inquiry, did Dawkins have to say that DNA is "selfish" if he wanted to make the point stick with those he was addressing that it is more explanatory and more parsimonious to look at natural selection as operating on behalf of genes than on behalf of the organisms that contain them? There are, or at least were in the 1970s, good reasons for saying this. The characterization made certain newly discovered facts intelligible. At the same time, selfishness and Darwinism, when combined, bring a lot of extra baggage with them too. Examples are perspicuous only when criticism blunts their tendency to become excessively persuasive, as this one did when Dawkins took it so seriously that he thought he had to defend materialism and atheism in order to protect his interpretation when its kairotic moment had passed (Depew, 2012).

\section{Authorizing Terms}

Persuasive examples, we think, are closely tied, when their force is spelled out, to authorizing terms. Here we encounter an issue about which the two of us talk a lot. The connection between local cases and high-level theories is so open that authorizing terms like "Darwinism" are not forced conclusions, but independent variables. Why do evolutionary scientists think they have to call what they are doing "Darwinism," especially since that term packs so much baggage that the insistence of scientists on it does more than anything else to keep creationism or intelligent design alive in the space of controversy as alternative authorizing terms? One of us tends to think that the ideograph "Darwinism" has been so poisoned by its history that it might be better to give it up altogether. What would be lost, he asks, if the scientific community took, say, a "Lamarckian" turn? Would this not let us see what experimental biologists are showing all the time these days? Genomes, it seems, are surprisingly sensitive to environmental changes. With more ease than would have been thought possible in the heyday of Francis Crick's "central dogma" (right: dogma) of molecular biology, they can intensify the rate at which genetic variation, the fuel of natural selection, occurs and can even hatch up regulatory sequences, micro-RNAs, epigenetic markers, and other bits of ontogenetic machinery to respond to environmental changes (Jablonka \& Lamb, 1995).

Still, we have to admit that Lamarckism lugs along some baggage too, such as Lysenkoism. Accordingly, the other of us is inclined to follow the lead of Theodosius Dobzhansky, whose genial and inviting rhetoric has been studied by Leah Cecarrelli (2001), in hoping to show the public that natural selection is actually a benign process that does not carry the negative connotations associated with so-called "social Darwinism." Which of us is right? We are not sure. What we are sure of is that this discussion puts the phenomena we are studying in the right, that is, the rhetorical, light. In that light, "Darwinism" and "Lamarckism" are authorizing terms. 


\section{Presumption and Burden of Proof}

No one, we hope, will construe our remarks as anti-science. So we take the opportunity to express our agreement with Celeste Condit that rhetorical scholars, in opposing scientism and its philosophical defenders, are ill advised to buy into an anti-science stance. Just as we do not think creationists should colonize evolutionary biology by making it conform to their worldview, neither do we think that literary humanists should be allowed to do something similar. We are afraid that social constructionism has fallen into that trap, and that this has been encouraged by certain trends in rhetorical theory. We hope we have given you reasons to see why we think we have evaded that approach.

We may put our point differently by noting something else about the rhetorical character of scientific argumentation. Since it is embedded in rhetorical occasions, scientific criticism, whether by scientists or informed others, is permeated by judgments about where presumptions and burdens of proof lie at any given time. These always favor maintaining or restoring a certain judicious balance between innovation and tradition. Accordingly, being a rhetorician who is pro-science does not require granting presumption to the latest thing to come out of scientific fields, especially fields that are clearly in an incipiently inventive stage. Among these are behavioral and cognitive genetics. The impulse to extend evolutionary biology to these topics runs very deep. But the track record of earlier attempts to bring these topics under scientific, even technoscientific, control is very poor, and the burden of proof remains on them.

The assumption that this burden is currently shifting is based on the idea that we now know enough about genetics to do the job. This assumption is probably wrong; or, even if it is right, it shows that we also need to know a lot about other things as well, such as development and its intersection with culture. So caution is advisable. Caution is particularly advisable because public sphere books and articles tend to place too great a value on particular discoveries that might have, we are always told, revolutionary implications. The language of a "gene for this" or a "gene for that" falls into this class of journalistic effects. In the technical sphere, however, things seldom, if ever, work that way. The latest and biggest thing soon turns into a single data point in an array that continues to change. The lesson is that rhetoricians of science must know enough about what is going on in the technical sphere to be able to address, and judge properly, its relevance to the public sphere. Rhetoric is about judgment-in science as in other dimensions of discourse.

\section{Inventing on All Cylinders}

Our emphasis on the productive role of rhetoric in the sciences has so far focused on how criticism fosters the growth of knowledge. But the productivity of rhetoric so considered also affects how we should think of inventing new hypotheses. That is, the rhetorical dimension of scientific activity makes us look to the question of how invention is doing work within science in ways that support many of the traditional aspirations of science in modernizing societies. 
Ever since the early days of rhetorical theory, topical and stasis theory has proven to be one useful way of thinking about invention. It has proven no less fertile in the sciences. Francis Bacon's view of scientific method was in fact an extension of the a-technical rhetorical proofs to scientific inquiry in a context of political improvement. Baconians might from the start have been more attuned to rational-discursive or technical rhetorical proof as well-ethos, pathos, and logos-and hence to the integral role of discourse of science that we have advocated. The motto of the Royal Society, nullius in verba, may be well taken as dissociating science from the decorative rhetoric of the day. But it is not in the least true about the role of rhetorical argumentation in science as it subsequently developed in modern societies. It has been full of ethos, pathos, and logos. Thankfully, the palette is slowly expanding in rhetoric of science work today and more generally in the work of contemporary science studies.

In the view we are advocating, invention, as we have already said, is not sudden inspiration. It is a process in which leads and topics are explored in as creative and systematic a way as Edison, for example, explored them (Bazerman, 2002). Because the inventional process is a critical, context-dependent practice, it does not stand in contrast to discovery or of proof. It is a process of discovery and proof. Since on this point we want once again not to play into the hands of those who might dismiss us as advocating some kind of effete textualism, we might picture a kind of spectrum on which discovery lies at one end and invention at the other, with most cases closer to one end than the other. In saying that a previously unknown species has been "discovered," we register that something ontological does indeed seem to be at stake, pulling us back from going as far as Latour when he maintains that microbes did not exist until Pasteur discovered them (Latour, 1988). Invention in our usage does not carry that force or implication. What it carries is the implication that when something gets called a discovery, a process of discourse has been found so persuasive that talk moves on to other things in which the discovery is taken for granted-although in principle it is re-visitable.

Below are a few dimensions of the inventive process as productive work in evolutionary biology, and mutatis mutandis, in science generally.

\section{Inventing Counter-Examples}

In debates over biological evolution, the use of carefully selected examples has often performed extensive rhetorical work in the advocacy of different explanatory models, as we have noted. As we say, the textbooks provide ample testimony of examples that have become so obligatory that they have exemplary status as standing for other similar things. Their persuasive function is that of metonyms or synecdoches: stand-ins for an entire underspecified class of other such things presumed to be "out there." One might think of this process as inventional and the corresponding practice of offering counter-examples as critical. But our way of thinking about invention suggests that there are just as many productive, inventive possibilities in scouting out counter-examples. Generating counter-examples is close to the core of scientific inquiry. It breaks up the rush to generalization that is inherent in using examples as paradigm cases. It is no surprise that Dawkins's selfish genes provoked 
researchers to find cases of group selection as counter-examples and that finding them has led to new truths about the biological, and especially the human, world.

\section{Inventing (and Expanding) the Scope and Texture of Context}

Not all rhetorical criticism should be tied to current circumstances. This is why Isocratean rhetoric, structured as it is by the pressing concerns of the kairos moment, is probably not enough for a satisfactory rhetoric of science. Nor is the kind of political reductionism we find in Shapin and Shaffer's Leviathan and the Air Pump (1989). In the context of the sciences, the pertinent circumstances are not just today and tomorrow. Rather, they pertain to a long-range trajectory in the pursuit of inquiry and should not be tied too closely to the ups and downs of political life. Nor should science be measured by how fast it produces technologies either, as seems to be the current zeitgeist. What used to be called basic research, for instance, is now often called "curiosity science." This is a very powerful act of renaming, because it makes concern for the longterm future seem like a kind of diversion, and thereby re-contextualizes those concerns. The concern with local context does not in the least contravene science's orientation toward the long run.

\section{Inventing Names}

The phrase "curiosity science" points to our next type of invention. Naming, mis-naming, and re-naming can be very powerful indeed. As Kenneth Burke (KB) put it, "A way of seeing is a way of not seeing" (Burke, 1984, p. 49). Burke was right about this point. Did you notice how fast some of the fast food chains capitulated when a particular substance in their hamburger patties was re-named "pink slime"? That was a brilliant rhetorical move, and a good counter-example to deterministic ways of thinking. Did you notice how support for the inheritance tax went down once it was re-named a "death tax"? Are these not in some ways similar to (and also different from) certain rhetorical moves emanating from the sciences-we're looking at you, "selfish gene" and "the Modern Synthesis"-even if there are generally more stringent checks on unfettered invention and more specificity to the available means of persuasion in those provinces? Names can be, as Fahnestock (2008) says of rhetorical figures in science, "figures of thought" (see also Fahnestock, this issue).

Here is a case very much to KB's point. Public attention has recently been called in a most dramatic way to that part of the genetic material that does not code for DNA, which is to say, most of it. The term "junk DNA" was coined in 1972 and has fanned out, first among prominent biologists and subsequently in widely across the general culture. Yes, this name was chosen to reflect a view, widely adopted at the time, that noncoding parts were also nonfunctional parts. In that sense and context, the term arguably did productive work in crystallizing the theoretical outlook that led to full understanding of the so-called genetic code, "coding" and "programming" being metaphorical terms that advanced this very local research program. But as that view gradually lost scientific credibility by its very success, leading to the epigenetic revolution that is upon us now, whole segments of the evolutionary biology community, in thrall to a 
name, remained largely blind to a revolution within the most respected precincts of molecular biology itself that has pointed to the importance of (noncoding) regulatory genes. The term "junk" continues to sustain a blinkered view of what genes are all about. This orthodoxy has borne down on many scientists as well as on that part of the public who read about such things. Change the names and you invent a better, truer future. Naming is framing. (The term, "dark matter" has been used in reference to noncoding genetic material. We are intrigued by the overtones and possible rhetorical destiny of that term.)

But naming has more systemic uses as well. One of these is in the maintenance of authorizing terms, the terms under which research programs are legitimated. On the matter of supporting a program by advocating for a term, Dawkins could not have said it better: "My contribution to the idea of the selfish gene," he wrote, "was to put rhetoric into it and spell out its implications" (Dawkins, 1995, p. 76). Dawkins here offers a stunningly direct acknowledgement of-indeed, an embrace ofthe rhetoricity of his project. This process of embracing a term and then justifying it occurs right in the thick of scientific theorizing, which Dawkins's inventional process also did, in addition to reaching a broader public. These discursive processes are going on all the time. So, for instance, as "autopoetic" theory bids for respectability in evolutionary theory, it relies on the name to do a lot of the work of coalition-making, opponent-defining, and concept-aligning, even as its arguments are not static. In that sense, the term is a call to "think this way." Advocates will search for reasons to support that way of thinking, and opponents will put forth reasons for not thinking that way. That's how it goes.

\section{Inventing Within a Dialogical Frame}

Let us bring to bear on the topic of invention our earlier insistence that science takes place within the space of implicit or explicit controversies. This being so, we should resist the tendency to think of scientific rhetoric as something that is monological, or something merely to be mapped, or something apprehended as text. Scientific arguments move forward by encounters with professional resistance, alternatives, counter-

interpretations, arguments about the reproducibility of results, theoretical or conceptual adjustments, biases, cultural and ideological resistance, and funding issues. They also move on the harnessed energy of theories, programs, technological promises, reputations, funding, and aspirations. These things constitute the rough ground that is presupposed in the discourse of science. We should be alert to the events and traumas that affect the movement of science as it responds to them. One of the challenges for competing accounts, in evolutionary biology and elsewhere, is to find ways of putting the dominant metaphors into some kind of dialogical relationship. This represents an inventional challenge for evolutionary biology particularly, and other fields generally. 


\section{Need We Be Unified?}

In her companion position paper to this one and others, Celeste Condit (this issue) has once again acted to stimulate democratic debate. In her survey, it is the purpose of studying the rhetoric of science and technology-not, as in ours, the process-that is given primacy; explicitly so in two of the categories of work covered in her overview: the purpose of building theory and the purpose of improving scientific rhetoric. These are purposes that we both can and in our way do sign on to, as we have been trying to suggest. The other two categories Condit has identified and summarized starkly as "science bad" and "science too powerful," might better be described as matters of "attitude" rather than purpose, and her point about the attitude rhetoricians of science should take toward them is our point too. Implicit in these two attitudes is oppositional motivation, and so it seems to have answered in advance and hence slightly begged, the question, “To what end?" or perhaps "In the service of what?" is this work undertaken?

Condit is no doubt right, however, to surmise that some members of our community share in the view of science against which she warns us. Here it seems that we rhetoricians of science and technology may have differences among us as a community of inquiry that have not been very well thematized and debated in our field. It is a situation we might rectify. As nothing unifies like an attack from the outside, Condit (this issue) points to a looming threat from the outside as a motivation to pull us together. We believe her concerns are well justified. If the very conditions under which we work are endangered, then rallying to preserve and protect values even more basic then the value of rhetoric of science is-as the physician might say- "indicated."

There is also risk in defining our purpose in political terms. Here we need to tread carefully. Nothing undercuts the credibility of scientific claims faster than when the messenger is seen as acting with political intent. Witness the extraordinary hit that belief in global warming took in public opinion after the "climategate" emails were politically exploited. And there are similar risks within academic institutions. We believe, for example, that the normative meta-theory adopted by advocates of STS has come at some cost to their credibility in some quarters (Collin, 2010). If we sign on to a set of political objectives in studying the rhetoric of science, do we risk activating ethos-damaging blowback? And, if so, is that a risk worth taking?

As diversity seems to be a good thing in both ecology and evolution, it might have some advantages for those who have been constructing an environmental niche for rhetoric of science. Work thus far has been highly varied in character. Perhaps that pluralism should be embraced rather than taken as a sign of weakness. Steve Fuller's view that we need a strong program in rhetoric of science, analogous to the strong program of social studies of science and technology, has some appeal (Fuller, 1995). We have done little, however, to relieve his predictable exasperation about the fact that we haven't endorsed this view or this analogy in this position paper. As a rhetorical framing, a strong program should beat out a weak program every time. But if we take the metaphor of niche 
construction as a heuristic, diversity need not equate to weakness. Fuller, after all, would have us follow him into places we might not want to go.

\section{Parting Thoughts}

Michael Pollan (2007) wrote a well-regarded book, The Omnivore's Dilemma, for which the title sets up his central question: Since humans can eat just about anything, how do we-meaning those of us who have the option of choosing-decide what to eat? How we answer that question has implications not just for our health, but for our environment, our ethics, and our politics as well. The contemporary rhetorician has a similar dilemma. When the world is your field, it's hard to know what to feast upon. We exaggerate slightly, if at all, in suggesting that rhetoric has taken the world and all that's in it -and potentially in it - as our field of concern.

The rhetoric of science has always lent itself to interdisciplinarity, but at times it seems to have its sights set on omni-disciplinarity. If other fields offer powerful explanations for the way things work-sociology, psychoanalysis, philosophy, neuroscience-then many of us want to harness power like that. From a historical viewpoint this is to be expected, as conceptions and practices of rhetoric have over the centuries been shaped by the social, political, and epistemic biases of their times. Moreover, rhetoric tends to gravitate to the centers of power and to adapt according to what that power is - the church, the king, the assembly, public opinion, funding agencies, and so on-for that is where it can matter most. We should therefore expect that the very powerful forces of science are magnets for rhetoric. But as rhetoricians we should want to be careful not to give up on the idea that there is power in rhetorical invention, for good or for ill, that it should be studied and engaged, and that this study need not be outsourced to other disciplines. If we succumb to determinisms that relegate discourse to the level of epiphenomena, we would do well to get on the wagon of some other field, such as sociology, economics, psychoanalysis, or neuroscience. But otherwise not.

Now rhetoric invites these fields, and practically all others, to help it see the terrain on which discursive interventions occur. But at the same time, it need not fade into the woodwork as it draws on the expertise of other fields. POROI was more or less founded on that understanding. It was an assumption of those who founded ARST, too, and we believe it is a shared assumption of most of those interested in the rhetoric of science and technology, including authors who, like ourselves, have worked collaboratively with folks from other disciplines. We have advocated for more attention to how rhetoric can be productive within science. Our perspective is that this process does not happen in a hermetically-sealed technical sphere, just as its consequences certainly do not confine themselves there. And that means that our perspective is very much proscience-and just as much pro-rhetoric.

\section{References}

Bazerman, C. (2002). The languages of Edison's light. Cambridge, MA: MIT Press. 
Burke, K (1984). Permanence and change (third edition). Berkeley, CA: University of California Press.

Collin, F. (2010). An alternative road for science and technology studies and the naturalization of philosophy of science." In F. Collin (Ed.), Science studies as naturalized philosophy (pp. 197-233). New York: Springer.

Ceccarelli, L. (2001). Shaping science with rhetoric: The cases of Dobzhansky, Schrodinger, and Wilson. Chicago, IL: University of Chicago Press.

Dawkins, R. (1995). A survival machine. In J. Brockman (Ed.). The third culture: Beyond the scientific revolution (pp. 74-95). New York: Simon \& Schuster.

Depew, D. (2010). Revisiting Richard McKeon's architectonic rhetoric. In M.J. Porrovecchio (Ed.), Reengaging the prospects of rhetoric (pp. 37-56). New York: Routledge.

----. (2012). The rhetoric of evolutionary theory. Biological Theory, 6, 110. doi: 10.1007/s13752-012-0054-2.

Fahnestock, J. (2008). Rhetoric in the natural sciences. In A. Lunsford, K. Wilson, \& R. Eberly (Eds.), SAGE handbook of rhetorical studies (pp. 175-196). Thousand Oaks, CA: Sage.

Fuller, S. (1995) The strong program in the rhetoric of science. In H. Krips, J. E. McGuire, T. Melia (Eds.), Science, reason, rhetoric (pp. 95-117). Pittsburgh, PA: University of Pittsburgh Press.

Gieryn, T. (1999). Cultural boundaries of science: Credibility on the line. Chicago, IL: University of Chicago Press.

Goodnight, G.T. (1982). The personal, technical, and public spheres of argumentation. Journal of the American Forensics Association, 18, 214-227.

Hauser, G., \& Cushman, D. (1973). McKeon's philosophy of communication: The architectonic and interdisciplinary arts. Philosophy and Rhetoric, 6, 21-34.

Jablonka, E., \& Lamb, M. (1995). Epigenetic inheritance and evolution: The Lamarckian dimension. New York: Oxford University Press.

Kevles, D. (1985). In the name of eugenics. Berkeley, CA: University of California Press.

Latour, B. (1987). Science in action: How to follow scientists and engineers through society. Cambridge, MA: Harvard University Press.

----. (1988). The Pasteurization of France. Cambridge, MA: Harvard University Press

----. (1993). We have never been modern. Cambridge, MA: Harvard University Press.

----. (2005). Reassembling the social: An introduction to actor-network theory. New York: Oxford University Press. 
McKeon, R. (1971). The uses of rhetoric in a technological age: Architectonic productive arts. In L. Bitzer \& E. Black (Eds.), The prospect of rhetoric (pp. 44-63). Englewood Cliffs, NJ: Prentice-Hall.

Pollan, M. (2007). The omnivore's dilemma: A natural history of four meals. New York: Penguin.

Rosenberg, A. (1994). Instrumental biology, or the disunity of science. Chicago, IL: University of Chicago Press.

Shapin, S., \& Shaffer, S. (1989). Leviathan and the air pump. Princeton, NJ: Princeton University Press.

Taylor, C.A. (1997). Defining science: A rhetoric of demarcation. Madison, WI: University of Wisconsin Press. 


\section{Appendix}

The following are examples from each of the variations on rhetoric of science studies that we have enumerated. Neither the categories of variation nor the exemplars are fully represented here. We used a version of Chicago style so that authors' full names appear.

1. Studies of major scientists include: John Angus Campbell, "The Polemical Mr. Darwin,” Quarterly Journal of Speech 61 (1975): 375-390; John Angus Campbell, "Scientific Revolution and the Grammar of Culture: The Case of Darwin's Origin," Quarterly Journal of Speech 72 (1986): 351-76; Leah Ceccarelli, Shaping Science with Rhetoric: The Cases of Dobzhansky, Schroedinger, and Wilson (Chicago, IL: University of Chicago Press, 2001); G. Mitchell Reyes, "The Rhetoric in Mathematics: Newton, Leibniz, Their Calculus, and the Rhetoric of the Infinitesimal," Quarterly Journal of Speech 90 (2004): 163-88; J. Zappen, "Francis Bacon and the Historiography of Scientific Rhetoric," Rhetoric Review 8 (1989): 74-88.

2. Studies of the rhetoric of scientific genres include: Charles Bazerman, Shaping Written Knowledge (Madison, WI: University of Wisconsin Press, 1988); Carol Berkenkotter and Thomas N. Huckin, Genre Knowledge in Disciplinary Communication (New York: Routledge, 1994); Alan Gross, The Rhetoric of Science (Cambridge, MA: Harvard University Press, 1990); Alan Gross, J. E. Harmon, and M. Reidy, Communicating Science: The Scientific Article From the Seventeenth Century to the Present (New York: Oxford University Press, 2002); Greg Meyers, Writing Biology: Texts in the Social Construction of Scientific Knowledge (Madison, WI: University of Wisconsin Press, 1990); Jack Selzer, ed., Understanding Scientific Prose (Madison, WI: University of Wisconsin Press, 1993).

3. Studies of rhetoric within particular scientific fields include: David Depew, "The Rhetoric of Evolutionary Theory, " Biological Theory 6.1 (2012): 1-10; Henry Howe and John Lyne, "Gene Talk in Sociobiology,” Social Epistemology 6 (1992), 1-54; Jordynn Jack and L. Gregory Appelbaum, “'This is Your Brain on Rhetoric': Research Directions for Neurorhetorics," Rhetoric Society Quarterly 40 (2012): 411-437; Zoltan P. Majdik, Carrie Anne Platt and Mark Meister, "Calculating the Weather: Deductive Reasoning and Disciplinary Telos in Cleveland Abbe's Rhetorical Transformation of Meteorology," Quarterly Journal of Speech 97.1 (2011) 74-99; Carolyn Miller, "The Rhetoric of Decision Science, Or Herbert A. Simon Says," in Herbert W. Simons, ed., The Rhetorical Turn: Invention and Persuasion in the Conduct of Inquiry (Chicago, IL: University of Chicago Press, 1990), 162-186; James Wynn, Evolution by the Numbers: The Origins of Mathematical Argument in Biology (Anderson, SC: Parlor Press, 2012).

\section{Studies of the rhetoric of scientific and technological} controversies include: Leah Ceccarelli, "Manufactured Scientific Controversy: Science, Rhetoric, and Public Debate," Rhetoric \& Public Affairs 14 (2001): 195-228; Nathan Crick and Joseph Gabriel, "The 
Conduit Between Lifeworld and System: Habermas and the Rhetoric of Public Scientific Controversies," Rhetoric Society Quarterly 3 (2010): 201-223; Thomas Lessl, "Heresy, Orthodoxy, and the Politics of Science," Quarterly Journal of Speech 74 (1985): 18-34; John Lyne and Henry F. Howe, "Punctuated Equilibria: Rhetorical Dynamics of a Scientific Controversy," Quarterly Journal of Speech 74 (1985): 18-34; Lisa Keränen, "Mapping Misconduct: Demarcating Legitimate Science from 'Fraud' in the B-06 Lumpectomy Controversy," Argumentation and Advocacy 42 (2005): 94-113; Gordon R. Mitchell and Marcus Paroske, "Fact, Fiction and Political Conviction in Science Policy Controversies, Social Epistemology 2-3 (2000): 89-107; Gordon Mitchell, Strategic Deception: Rhetoric, Science, and Policy in Defense Advocacy (East Lansing, MI: Michigan State University Press, 2000); Marcus Paroske, "Deliberating International Science Controversies, Uncertainty and AIDS in South Africa," Quarterly Journal of Speech 95 (2009): 148-170.

5. Studies of rhetorical invention in science include: John Angus Campbell, "Scientific Discovery and Rhetorical Invention: The Path to Darwin's Origin," in Herbert Simons, ed, The Rhetorical Turn: Invention and Persuasion in the Conduct of Inquiry (Chicago, IL: University of Chicago Press, 1990); Alan Gross and William Keith, Rhetorical Hermeneutics: Invention and Interpretation in the Age of Science (Albany, NY: SUNY, 1997); Lawrence J. Prelli, A Rhetoric of Science: Inventing Scientific Discourse (Columbia, SC: University of South Carolina Press, 1989); Herbert Simons, The Rhetorical Turn: Invention and Discovery in Conduct of Inquiry (Chicago, IL: University of Chicago Press, 1990).

6. Studies of episodes in the history of science include: Lisa Keränen, Scientific Characters: Rhetoric, Politics, and Trust in Breast Cancer Research (Tuscaloose, AL: University of Alabama Press, 2010); Jean D. Moss, Novelties in the Heavens: Rhetoric and Science in the Copernican Controversy (Chicago, IL: University of Chicago Press, 1993); Dale Sullivan, "Galileo's Apparent Orthodoxy in The Letter to the Grand Duchess Christina,” Rhetorica 12 (1994): 237-264.

7. Studies of public appropriations of scientific terms include: Celeste M. Condit, The Meanings of the Gene: Public Debates about Human Heredity (Madison, WI: University of Wisconsin Press, 1999); Marita Gronnvoll and Jamie Landau, "From Viruses to Russian Roulette to Dance: A Rhetorical Critique and Creation of Genetic Metaphors, Rhetoric Society Quarterly 40 (2010): 46-70.

\section{Studies of language and figures within science include:} Jeanne Fahnestock, Rhetorical Figures in Science (New York: Oxford University Press, 1999); Thomas Frentz, "Creative Metaphors, Synchronicity, and Quantum Mechanics," Philosophy and Rhetoric 12 (2011): 101- 128; E. F. Keller, Refiguring Life: Metaphors of TwentiethCentury Biology (New York: Columbia University Press, 1995); Scott Montgomery, The Scientific Voice (New York: Guilford Press, 1996); Carol Reeves, The Language of Science (London, England: Routledge, 2005). 
9. Studies on incommensurability and the relationships among disciplines include: Randy Allen Harris, The Rhetoric of

Incommensurability (West Lafayette, IN: Parlor Press, 1997).

10. Studies of rhetoric and philosophical rationality include: M. A. Finocchiaro, Galileo and the Art of Reasoning: Rhetorical Foundations of Logic and Scientific Method (Dordrecht, Netherlands: Reidel, 1980); Henry Krips, J. E. McGuire, and Trevor Melia, eds., Science, Reason, and Rhetoric (Pittsburgh, PA: University of Pittsburgh Press, 1995); Steven Fuller and James Collier, Philosophy, Rhetoric, and the End of Knowledge, 2nd ed. (Mahwah, NJ: Lawrence Erlbaum, 2003); Jean D. Moss and W. A. Wallace, Rhetoric and Dialectic in the Time of Galileo (Washington, DC: Catholic University of America Press, 2003); M. Pera and W. R. Shea, Persuading Science: The Art of Scientific Rhetoric (Canton, MA: Science History, 1991).

11. Studies of the rhetorical uses of expertise include: Thomas B. Farrell and G. Thomas Goodnight, "Accidental Rhetoric: The Root Metaphors of Three Mile Island," Communication Monographs 48 (1981): 270-300; Johanna E. Hartelius, The Rhetoric of Expertise (Lanham, MD: Lexington Books, 2011); James W. Hikins and Richard Cherwitz, "On the Ontological and Epistemological Dimensions of Expertise: Why 'Reality' and 'Truth' Matter and How We Might Find Them," Social Epistemology 24 (2011): 291-308; John Lyne and Henry F. Howe, "Rhetorics of Expertise: E. O. Wilson and Sociobiology," Quarterly Journal of Speech 76 (1990): 134-151, Damien Smith Pfister, "Networked Expertise in the Era of Many-to-many Communication," Social Epistemology 25 (2011): 217-231; Zoltan Majdik, "Judging Direct-ToConsumer Genetics: Negotiating Expertise and Agency in Public Biotechnological Practice," Rhetoric \& Public Affairs 12.4 (2009): 571606.

12. Studies of the rhetoric of medicine include: Michael Hyde and J. McSpiritt, "Coming to Terms With Perfection: The Case of Terri Schiavo," Quarterly Journal of Speech 93 (2007): 150-78; Lisa Keränen, "'Cause Some Day We All Die': Rhetoric and the Case of the 'Patient' Preferences Worksheet," Quarterly Journal of Speech 93 (2007): 179210; John Leach and Deborah Dysart Gale, eds., Rhetorical Questions of Health and Medicine (Lanham, MD: Lexington Books, 2010); Judy Z.

Segal, Health and the Rhetoric of Medicine (Carbondale, IL: University of Southern Illinois Press, 2005); Celeste M. Condit, "Women's

Reproductive Choices and the Genetic Model of Medicine," in M. M. Lay, L. J. Gurak, C. Gravon, and C. Myntti, eds., Body Talk: Rhetoric,

Technology, Reproduction (Madison, WI: University of Wisconsin Press, 2000), 125-41.

13. Studies of rhetoric and materiality include: Celeste M. Condit, "Race and Genetics From a Modal Materialist Perspective," Quarterly Journal of Speech 94 (2008): 383-406; John Lynch, "Articulating Scientific Practice: Understanding Dean Hamer's 'Gay Gene' Study as Overlapping Social, Rhetoric, and Material Registers," Quarterly Journal of Speech 95 (2009): 435-456. 
14. Studies in the rhetoric of risk include: G. Thomas Goodnight and Sandy Green, "Rhetoric, Risk, and Markets: The Dot-Com Bubble," Quarterly Journal of Speech 96 (2010): 115-140; Lisa Keränen, "Catastrophic Risk and the Production of Bio(in)security," Western Journal of Communication 75 (2011): 451-472.

15. Studies in the visual rhetoric of science include: Michelle Gibbons, "Seeing the Mind in the Matter: Functional Brain Imagine as Framed Visual Argument, Argumentation \& Advocacy 43 (2007): 175188; Alan Gross, "Toward a Theory of Verbal-Visual Interaction: The Example of Lavoisier, Rhetoric Society Quarterly 39 (2009): 147-169; Jordynn Jack, “A Pedagogy of Sight, Microscopic Vision in Robert Hooke's Micrographia," Quarterly Journal of Speech 95 (2009): 192209; Lawrence Prelli, ed., Rhetorics of Display (Columbia, SC: University of South Carolina Press, 2006); Lynda Walsh, "Before Climategate," Poroi 6 (2010): 3-33.

16. Studies of mythic rhetorics of science and religion include: James Herrick, Scientific Mythologies: How Science and Science Fiction Forge New Religious Beliefs (Downers Grove, IL: IVP Academic, 2008), Thomas Lessl, Rhetorical Darwinism: Religion, Evolution, and the Scientific Identity (Waco, TX: Baylor University Press, 2012). 